The Labore Journal of Economics

Special Edition

\title{
Entrepreneurship, Private Investment and Economic Growth
}

\section{Manzur-ul-Haq*}

\section{Introduction}

Despite impressive macroeconomic indicators, Pakistan's economy has not shown the kind of investment and employment generation performance which is required to move the country on to a growth trajectory which will mean significant reduction in poverty levels and substantial improvement in its social indicators.

As can be seen from Figure 1, Pakistan's investment gap widened with comparable countries during the nineties.

Figure-1. Aggregate Investment Gap with Competitors

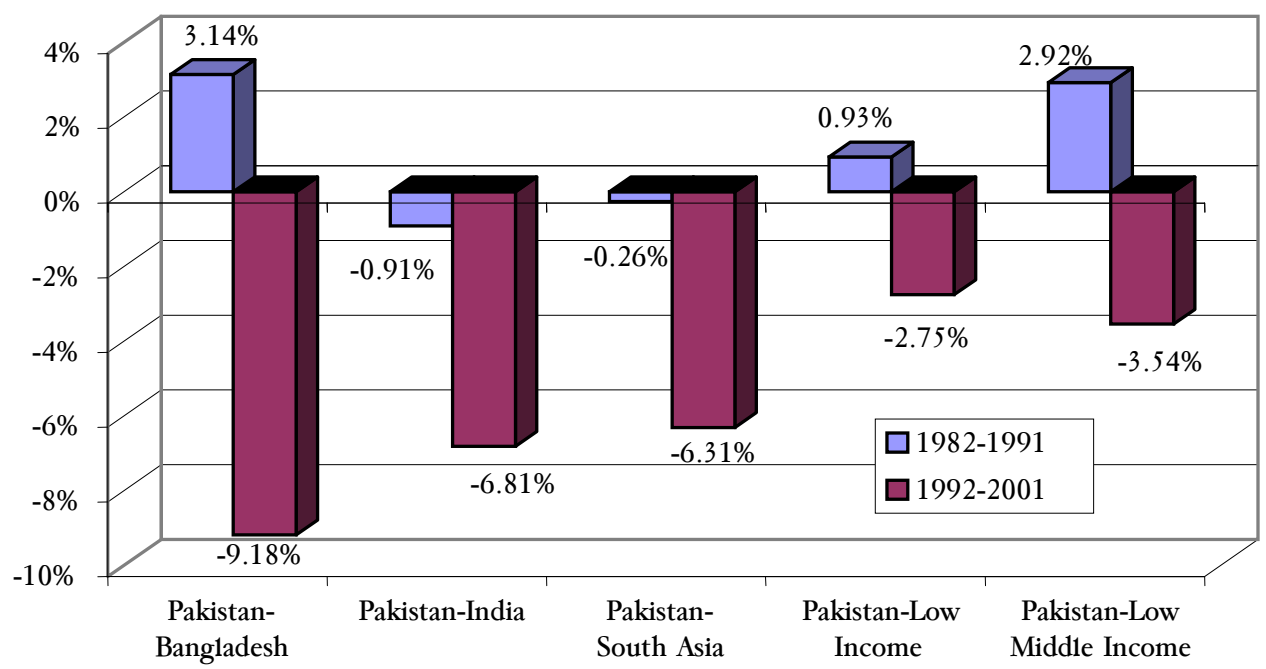

Source: Nabi, I

This downward trend is mirrored in the case of private sector investment also. Figure 2 shows trends in the private sector investment as a

${ }^{*}$ The author is Chief Executive, International Housing Finance Ltd. 
percentage of GDP. Not only have the rates been below those of our neighbours, the trend itself is downwards and, if anything, has accentuated in its decline in the last few years.

It is estimated that private investment will have to grow by $9 \%$ on a yearly basis over the next two decades simply to catch up with its own growth path projected on the basis of growth in the eighties.

Little wonder that Pakistan ranks at the very bottom in competitiveness in most international comparisons. Given the composition of its population, perhaps the most disastrous effects have been on employment in general and educated employment in particular.

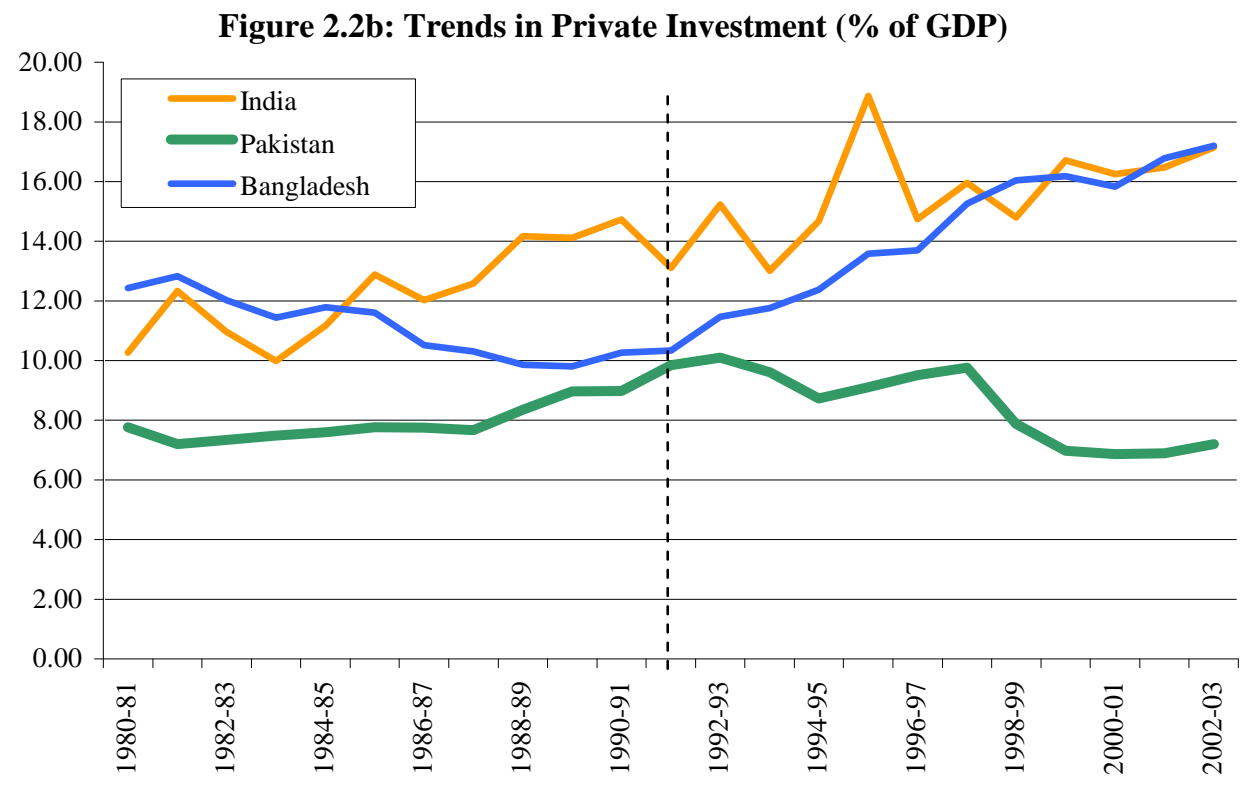

Source: World Development Indicators 2004. Pakistan Economic Surveys 1987-88, 1992-93. 200.3-04

Both the imperatives of employment and investment have to be addressed by the private sector which has to be in the vanguard of a modem economy. These tasks have to be carried out throughout the business sector. No only is it important that the existing firms display vigour, creativity, courage and innovation, but also that new entrepreneurial firms continuously come into being and survive to adulthood, creating the desperately needed growth in jobs and investment and address the decline depicted in figure- 2 . 
The business sector comprises individuals acting as economic agents on their own or as groups organized as firms and businesses. Economic growth is essentially dependent on the motivation, quality and effectiveness of these agents.

This paper focuses on the entrepreneur and entrepreneurship as the primary instigators of economic growth. For our practical purposes, the entrepreneur is the individual who starts a business enterprise. He takes his destiny in his (or her) own hands, invests his (or her) own capital (or borrows it), bears the risk of the unknown and becomes the change agent in a society.

In Section 2 we will go on to examine the attributes of the entrepreneur and his unique functions in an economy and in instigating economic growth.

Section 3 will consider the entrepreneurship framework of our economy and hence the context within which wealth-creation takes place. Section 4 will focus on the Pakistani entrepreneurial scene. The last section will present some recommendations with a view to improving the environment for entrepreneurial activity.

\section{Entrepreneurship and Economic Growth}

The role of the entrepreneur in economic development is central; he starts businesses and provides jobs. Although all businesses are reflections of enterprise, the small-scale sector (with less than 100 employees) is perhaps the most explicit example of the individual business entrepreneur at work. In Pakistan this sector provides $80 \%$ of non-farm employment, contributes $40 \%$ to GDP and has a $25 \%$ share in the country's exports.

This is more or less consistent with most other economies. In the U.S, the small scale sector created millions of jobs in the last decade and has been the engine of growth which has provided close to full employment in a large economy. Many other countries show the same phenomenon to varying degrees.

Entrepreneurship in its truest sense is about innovation and changing the status quo. (P. Drucker, J. Schumpeter). This is, perhaps, at the core of economic transformations, the internet revolution, the knowledge-based organization and so on. 
In the case of Pakistan, the green revolution in agriculture, the industrialization of the ' $60 \mathrm{~s}$ and the development of the textile industry in the ' 80 s and ' 90 s are some of the examples of transformative entrepreneurial activity.

This kind of innovation is not of course confined to business. Innovative and far-reaching changes in social institutions and technological and scientific discoveries, for example can affect an economy profoundly. The setting up of schools and universities in the private sector or not-forprofit hospitals and environmental NGOs are examples of such social innovations in our own context.

While critically important in the development context, these societal innovations are not the subject of this paper. For our purposes, we will confine ourselves to the business entrepreneur.

Interestingly, the role of the entrepreneur in economic development theory has not been properly incorporated. Baumol ${ }^{1}$ in his 1993 article "Formal Entrepreneurship Theory in Economics: Existence and Bounds" writes:

"It seems to be taken for granted in the literature that, even if entrepreneurs are not in complete control of our economic destiny, they influence its direction as few if any others, are able to do. But having acknowledged this, implicitly or explicitly, normally no more is done to incorporate the entrepreneur's role into the mainstream models of value theory or the theory of the firm."

The same author writing in $1968^{2}$ says:

"The entrepreneur is at the same time one of the most intriguing and one of the most elusive characters in the cast that constitutes the subject of economic analysis. He has long been recognized at the apex of the hierarchy that determines the behaviour of the firm and thereby bears heavy responsibilities for the vitality of the free enterprise society."

Thus economic development takes place by ambitious individuals exploiting innovative ideas, new technologies or new knowledge to create wealth and jobs.

1,2 Lowery 
This causality of economic growth has been debated, to be sure (Baumol and others). Whether it is economic growth that causes a rise in entrepreneurial activity and leads to innovation or the other way around has important policy implications.

"It has been argued that entrepreneurship is omnipresent and, therefore, cannot be the 'cause' of development .......... simply put, economic growth, driven by entrepreneurship, cannot be explained without reference to institutions" (Boettke).

This view emphasizes the role of institutions and a basic framework to facilitate the ideas of risk-taking and innovation.

The role that various framework conditions play in encouraging or impeding entrepreneurial activity will be examined in more detail in section 3 , but for practical purposes, the motivated entrepreneur is the essential element in the system and without him the necessary conditions will not be met.

One of the findings of the GEM study (explained more fully in section 3 below), which is carried out across countries representing over $60 \%$ of the world's population and over many years is:

"in correlating the level of entrepreneurial activity with projected economic growth, it was found that necessity-based entrepreneurship is strongly correlated with projected economic growth, but not the opportunity-based entrepreneurship, which was rather difficult to explain” (GEM India Report 2002)

The difference is, of course, important as economies exhibit more opportunity-based entrepreneurship when they are undergoing periods of prosperity and expansion which produce these opportunities. In this case, the increased (opportunity-based) entrepreneurial activity is really a consequence of these positive developments and their cause.

We can see this in the case of the U.S.A in 2003, where Total Opportunity-based Entrepreneurial Activity (TEA) was 9.1\% and necessitybased TEA only $1.7 \%$. Thus only very few people were pursuing selfemployment because of lack of opportunity.

The Indian case again illustrates this. In 2001 necessity-based entrepreneurship was far higher at $7.5 \%$ than opportunity-based entrepreneurship of $3.7 \%$. This totally reversed itself $\mathrm{m} 2002$ with 
opportunity-based entrepreneurship at $12.2 \%$ and necessity-based TEA at $5 \%$. The authors of the India GEM report attribute this to a real positive change in the level of opportunities available in the economy, although they concede it may partly be attributable to changes made in sampling procedures, (India GEM Report 2002).

In relatively poor economies, it would be seen that necessity-based entrepreneurship is the dominant kind (e.g. India, Pakistan) while in richer economies like the U.S. the opportunity - based entrepreneur is more prevalent. This is, perhaps, to be expected.

This distinction of the entrepreneur also carries to the nature of firms being created. Thus, in poorer economies the firms are most likely low in capital, the business is predominantly low-tech and generally low in productivity and quality of products.

The kind of entrepreneur is also different in both these cases. In the former case, he is likely to have a lower education level and will engage mostly in "imitative" business activity. The size of firms will also remain small. In the latter case (e.g. U.S.) he is likely to be better educated than the average population, creates many high-tech ventures and is more likely to employ more people in the venture than his poor-country counterpart.

This is, again, perhaps, to be expected. While the very act of entrepreneurial firm-creation is a positive act for the economy and adds value, if the above state of affairs continues, it will probably mean that rich economies remain rich or become even richer, while the poor ones are doomed to remain trapped in a low-tech, low-productivity equilibrium. The obvious answer is to tap the high-growth producing entrepreneur in these societies; the one who will have the vision, managerial capabilities and innovative ideas to bring about a change. Joseph Schumpeter termed the actions of this kind of entrepreneur as causing 'creative destruction' in the status quo. In a developing economy like Pakistan, he is more likely to be filling a crucially-important void and providing it the impetus to grow; and thus breaking out of the low-level equilibrium state.

It is important to realize that entrepreneurship (as opposed to the individual entrepreneur) is a system within which there is the interplay of the environmental factors which include the societal norms, values and institutions and a host of other economic variables such as availability of credit, barriers to entry for new firms and property rights, amongst others. The Government is an important party in this system. 
Lowrey (2003) sums it up as follows:

"A well-defined entrepreneurship must include the social constitution, of which each economic man must be granted the basic rights: the right of free enterprise and the property (including intellectual property) right. People are granted the "human right" so that each human being must have the right to be a human, regardless of such things as gender, race, health condition, or social status. Each entrepreneur must have the fundamental right to engage in activities to survive and to advance in the economy. Entrepreneurship also must include the economic infrastructure, of which logistical arrangements such as roads, power grids, waterways, airports, education system, communication system, legislative system, financial system and market structure that are all effectively organized and designed for supporting entrepreneurial activities.'

In the next section we shall see that an attempt has been made to build a framework for judging the contribution of many of these variables to the level of entrepreneurial level in a society.

\section{Economic Growth and the Entrepreneurship Framework}

How does one gauge the health of the entrepreneurship system in a country? In the long run, of course, the rate of economic growth itself demonstrates the effectiveness of a nation's entrepreneurial activity. What the overall figures do not show, however, are the areas of particular concern or strength.

To understand the context of a country's entrepreneurial activity a useful construct is to look at the variables which make up the context in which economic growth takes place. A useful way of looking at the whole context within which an entrepreneur operates has been developed by the Global Entrepreneurship Monitor (GEM) study. This is a comprehensive study initiated by the London Business School and Babson College in 1999 on an annual basis. The main objective of the study is to assess the level of entrepreneurial activity across countries and over time. By 2003, the study covered 40 countries and over $60 \%$ of the world's population.

The basic postulate of the model is that there are societal/ institutional framework conditions in a country whose quality impedes or encourages entrepreneurial activity, which in turn influences economic growth. The framework conditions range from the cultural and social 
support of entrepreneurship to adequacy of physical infrastructure. A list of the 2002 framework conditions is given below:

1. Financial support to New Firms

2. Government Policy on New Firms

3. Government Programs for New Firms

4. Education and Training Support

5. Research and Development Transfers

6. Commercial, Legal and Professional Infrastructure

7. Market Openness and Ease of Entry

8. Adequacy of Physical Infrastructure

9. Appropriateness of Social and Cultural Norms

These nine framework conditions were later expanded to 14 in the current year by splitting one and adding four others. The original dimension of "socio-cultural Norms" was split into "Social Support" and "Cultural Norms". The four additional aspects that were investigated in 2002 were: (i) Opportunities for New Venture Creation, (ii) Entrepreneurial Capacity (iii) Intellectual Property Rights (IPR) Law and Enforcement, and (iv) Facilitation for Women Entrepreneurs.

(Source GEM India Report 2002)

Some of the findings of the 2002 study were:

$\checkmark 12 \%$ of the worlds' population in the 18-64 year range are entrepreneurial.

The number varies from country to country. It was less than $3 \%$ for Japan and more than $18 \%$ for India and Thailand.

The country groups graded from high to low are as follows:

$\checkmark$ Developing Asian Countries.

$\checkmark$ Latin American Countries.

$\checkmark$ Former British colonies outside Asia, 


\section{$\checkmark$ European Countries.}

\section{$\checkmark$ East European Countries.}

\section{$\checkmark$ Developed Asian Countries.}

Predictably the U.S. emerges as the leader amongst the G7 countries and outranks the rest of the world on key conditions such as financial support, entrepreneurship education and training and social norms favouring entrepreneurship. To quote from the 2003 U.S. report.

"The U.S, entrepreneurial landscape exhibits some very strong positive characteristics;

$\checkmark$ The culture of the United Stales is one of seeking opportunities and taking risks. The high ranking of the United States in this area is indicative of the country's distinct entrepreneurial orientation and continues to be a strong differentiating factor.

$\checkmark$ Among other things, the U.S. population shows a strong perception of having sufficient skills and abilities to start a new business, relatively low fear of failure, and relatively high alertness to unexploited opportunities.”

\section{(Source: U.S. 2003 GEM report)}

In the next section we shall use this framework to try to understand and evaluate the entrepreneurial activity underway in Pakistan.

\section{The State of Entrepreneurship in Pakistan}

Entrepreneurial activity is made up of innovative highly-motivated individuals who, to be effective transformers of an economy need a nurturing, supportive environment and a system which addresses the economic variables of his activity in a positive way.

It is a truism that a society's norms will also be reflected in its entrepreneurs, like in all its members. In a society characterized by low educational attainments, abject poverty, primitive living conditions, is it any wonder that we produce entrepreneurs who are generally necessity-driven individuals with low educational attainments who set up ventures employing little capital, which are low in productivity and do not use technology to any appreciable extent? 
Given their general background and the limitations imposed by the educational system, it what has been achieved is creditable.

To be fair, value-added businesses have been established in a multitude of sectors. Examples are hospitals, schools, universities, internet services, software houses, cable and TV channels, the fashion industry, construction and real state, restaurants, and so on. The textile, food and automobile sector have also demonstrated sizable investments. Most of the investment in these sectors are for existing large scale firms and, though relevant are not the major face of this study. Figure-3 shows investments made by the manufacturing sector over the years.

Figure-3: Industrial Performance 1949-2003

\begin{tabular}{lrrrrrc}
\hline \multirow{2}{*}{ Year } & \multicolumn{3}{c}{ Manufacturing Share in GDP } & \multicolumn{3}{c}{ Growth rates of Manufacturing (\%) } \\
& Total & Large Scale & Small Scale & Total & Large Scale & Small Scale \\
\hline $1949-50$ & 6.39 & 1.83 & 4.56 & 8.39 & 23.42 & 2.34 \\
$1959-60$ & 9.91 & 5.67 & 4.23 & 2.53 & 2.75 & 2.25 \\
$1969-70$ & 13.44 & 10.46 & 2.98 & 11.32 & 13.95 & 2.98 \\
$1979-80$ & 14.51 & 10.55 & 3.95 & 10.25 & 10.96 & 8.40 \\
$1989-90$ & 17.59 & 12.70 & 4.89 & 5.72 & 4.73 & 8.40 \\
$1999-00$ & 16.66 & 11.65 & 5.03 & 4.53 & -0.01 & 5.31 \\
$2000-01$ & 17.66 & 12.48 & 5.18 & 8.21 & 9.46 & 5.31 \\
$2001-02$ & 17,94 & 12.66 & 528 & 5.00 & 4.87 & 5.31 \\
$2002-03$ & 18.39 & 13.09 & 5.30 & 7.67 & 8.65 & 5.31 \\
\hline & & & Period Averages & & \\
\hline $1950 \mathrm{~s}$ & 8.78 & 4.38 & 4.41 & 7.73 & 15.75 & 2.3 \\
$1960 \mathrm{~s}$ & 12.41 & 8.85 & 3.56 & 9.91 & 13.39 & 2.91 \\
$1970 \mathrm{~s}$ & 13.99 & 10.423 & 3.57 & 5.50 & 4.84 & 7.63 \\
$1980 \mathrm{~s}$ & 16.65 & 12.26 & 4.38 & 8.21 & 8.16 & 8.4 \\
$1990 \mathrm{~s}$ & 17.68 & 12.32 & 5.36 & 3.88 & 3.54 & 5.06 \\
$1950-03$ & 13.37 & 9.27 & 4.09 & 6.78 & 8.78 & 5.06 \\
\hline
\end{tabular}

Source: 50 Years of Pakistan Volume I Summary, Statistical Supplement of Economic Survey, 2002-03 and Economic Survey 2003-04. From: Nabi, I. et al. 
Many new businesses being created are in the service sector, whose growing share in the GDP itself is testimony to the appreciable activity and the contribution of this sector to the economy.

As we have seen above, however, all this has still meant that we are caught in a low investment, low output trap. The authors of the India GEM Report, despairing, likewise write;

"There could also be one other reason for the seemingly unrelated movement of entrepreneurial activity and economic growth. It may be noted that one of the findings of the study was that a very large majority of the start-ups were 'imitative' ventures in the low-tech areas operated by less educated, low-income groups, with very low potential for growth. These are probably not the kind of ventures that can stimulate the economy- The findings thus confirm the need and relevance of the innovative, growth-oriented entrepreneur (the Schumpeterian type) for stimulating economic growth.”

\section{(India GEM Report 2002)}

As Pakistan is not a member of the GEM study yet, we can only try to relate some of the framework variables of this study which we looked at in section 3 above to our own non-empirical experience. A recent study (2003) done by the Small and Medium Enterprise Centre (SMEC) at LUMS of 650 SMEs in the manufacturing sector can also be used to draw inferences about the state of entrepreneurship in Pakistan. Papanek's study, though dated, still provides useful insights into the entrepreneurial process in Pakistan.

The majority of firms (78.8\%) in the LUMS study did not intend to make any investments in equipment/machinery over the next three years. The major reason by far $(27.6 \%)$ was expensive utilities/electricity. $9.2 \%$ cited problems of official bureaucracy as the reason and $5.8 \%$ law and order problems. Lack of demand was stated to be a reason by $10.9 \%$ of the participants, ahead of those giving difficulty in obtaining finances as a factor (8.47\%).

\section{The Enabling Environment}

The cultural and social factors were not part of the LUMS questionnaire.

The role that cultural variables play in making societies what they are is obvious; some societies are probably more entrepreneurial than others, 
although the incidence of entrepreneurship in over $12 \%$ of the population universally does mean that it has to be spread over all societies fairly evenly. The Total Entrepreneurial Activity (TEA) does, however vary significantly. As we have seen above, it is $3 \%$ in the case of Japan and $11 \%$ in the case of the U.S.A and $18 \%$ in the case of Thailand and India. This probably also reflects the development stage of a society, (e g. so that a higher TEA of necessitydriven individuals drives up the total TEA) or the institutional arrangements that a society prefers (in Japan the preferred individual entrepreneurial role may be within firms and self-employment is culturally not highly valued, while in the U.S. self-employment is a reflection of the freedom of the individual which is so highly prized). There have been a number of sociological theories of entrepreneurship. Perhaps the starting point was Max Weber's ideas about the influence of religion in the development of business enterprises (Protestantism in this case applied to the U.S.). Obviously cultural (and therefore, religious) norms are important in influencing behavior. What are our cultural norms in influencing the development of business? Zafar Altaf touches on this in his work of the ' 80 s, but generally relates it to the work ethics engendered by informal religious education. Obviously the more conservative and rural entrepreneur (who is naturally in a majority) is influenced by a different set of values than his westernized, better-educated, urban colleague.

The cultural influences are probably implicit in the following spheres;

$\checkmark$ The choice of business

$\checkmark$ The attitude towards wealth accumulation and investment

$\checkmark$ The attitude towards financing, in particular, towards interest-based financing

$\checkmark$ The views on insurance

$\checkmark$ The treatment of workers and customers

$\checkmark$ The view on taxes

$\checkmark$ Doing business with non-Islamic communities, and so on.

This is a whole field which needs greater exploration and could yield many policy options.

Zafar Altaf also examines the supposed attributes of various castes (Sheikh, Arain, Jat, etc.). While something can be said about the endowment of business acumen of various communities or concentration of 
populations (e.g. Latins and Asians in the U.S.) and there are obvious preferences of families or communities, the nature of entrepreneurial ability seems to be spread throughout the populations and a case may be made that it is the incentive structure and the ease of entry which are probably key to this. As Baumol says:

"While the total supply of entrepreneurs varies among societies, the productive contribution of the society's entrepreneurial activities varies much more because of their allocation between productive activities such as innovation and largely unproductive activities such as rent seeking or organized crime. This allocation is heavily influenced by the relative payoffs society offers to such activities."

In the case of India, the GEM findings show overall cultural support of entrepreneurship to be about at the average level of the sample. It was higher than the average in the case of support of risk taking and in encouragement of creativity and innovativeness. I do not think we can say the same about our society.

\section{Market Openness and Ease of Entry}

India scores almost the highest in terms of opportunities for new firm creation. I think our general investment climate has become better in the last couple of years. This can also be seen in the investments of the large - scale sector, which have been on the rise. In this respect the pessimistic outlook (no intention to invest in the near future of the majority in the LUMS survey is surprising.

Almost $67 \%$ of the respondents in the LUMS survey were first generation entrepreneurs, but $44 \%$ said they had relatives who were in business. Experience would suggest that it is not easy to set up a business in Pakistan; and for much of the time people set up a business if they already have a family background of business. India scored worse than average in the GEM survey on this account.

Papanek had found that ethnic groups constituting $0.5 \%$ of the population had provided $43 \%$ of Pakistan's industrialists in the '60s. Zafar Altaf s sample of 195 industrialists in 1980 showed that $70 \%$ came from a trade or industrial background.

This means that we are probably not attracting enough capable people with varied backgrounds into business who could bring fresh thinking and new blood to the economy. 
This could perhaps be a reason also why not enough innovative and new-product based ventures are being created. It would also seem that women entrepreneurs are probably far below the world average of $35 \%$ in Pakistan. We are mining out on a significant potential supply of very capable, intuitive and creative talent represented by our well-educated women, many of them in business and management.

\section{Access to Finance}

Only $50 \%$ of the organizations in the LUMS survey had a bank account. In line with other countries, capital for start up is generally from family and friends (even in the U.S. formal venture capital is a fraction of the U.S. \$ 100 billion invested annually in new ventures - GEM U.S.A. Survey 2003).

Even so, formal finance in Pakistan is at a very low level of availability for small firms. An estimate is that only about $7 \%$ of funds for investment and working capital are from banks or other financial institutions (SMEDA). If one looks at the total lending of Rs. 247 billion by commercial banks at end Sept. ' 04 to the SME sector (see appendix) the extent of the potential of the sector becomes obvious. The LUMS sample had taken around $19 \%$ of Running Finance requirements and around 16\% of fixed investments from commercial banks. These are probably the bigger firms in the survey. A formal venture capital industry is only in its rudimentary stage in Pakistan.

The bigger firms have more access to capital, of course. What is more important perhaps, is the availability of capital at the beginning of a firm's life.

It is interesting to see that in India, credit to the small scale sector as a percentage of total net bank credit from public sector banks at the end of March 1999 was 17.37 up from $15.3 \%$ four years earlier. This was not much different from $18 \%$ today in the case of Pakistan. It is probably not just about credit, but as to where it is available and at what stage of a firm's development.

\section{Property Rights and Intellectual Property Rights}

Many of the assets of the small sector are not fungible and trademark and other intellectual property protection laws are difficult to implement. These probably prevent licencing and most likely, retard research.

\section{Education and Training}


Around $57 \%$ of the LUMS entrepreneurs have an education level of matric or less. Only $6 \%$ use a computer. Papanek had also found that in the '60s entrepreneurs did not have much formal schooling, as did Zafar Altaf in the '80s. In the last forty years things have not improved significantly, although the trend is slightly positive. While informal schooling and experience make up for a lot, this kind of formal education does limit the kind of ventures which are founded, and their growth once they come into being.

Although India also reflects this, countries like the U.S. have individuals better educated than the average entering the business sector; which means more high-tech products, better utilization of research, better communications, and better managerial abilities, giving the firms a better chance of survival and growth.

\section{Government policies $\&$ interaction}

Only $32 \%$ of the respondents knew about the SME Bank and even fewer about other institutions, and almost $90 \%$ had never been contacted by government organizations. The owners and senior officials spend an average of 164 hours a month dealing with government organizations, principally WAPDA and the tax department.

The picture that emerges of the small entrepreneur or a new business owner is generally that of a necessity-driven person who has other family members in business, is poorly educated in and is generally short of capital and electricity.

He (overwhelmingly more than a she) is a representative of our social and value system and in his hands lies the destiny of our nation.

\section{Conclusion \& Recommendations}

This paper has briefly examined the phenomenon of entrepreneurial activity and its central position in economic growth. While the causality of economic growth stemming from greater entrepreneurial activity may be a matter of debate, in practical terms the two reinforce each other; greater opportunities provided by a growing economy spur greater entrepreneurial activity, which in turn provides the jobs and innovation which are the lifeblood of wealth-creation in the economy. This is the virtuous circle that all economies strive for.

For entrepreneurial activity to play its creative role to its full potential, it is important that the enabling conditions are improved and a supportive environment for new-venture formation is created. The principal aim of a program of incentives has to be to create a context within which 
the best-suited individuals in society are motivated to become entrepreneurs and thus wealth-creators for the nation.

The quality of entrepreneurial activity in Pakistan will improve as the overall context will become better, the quality and spread of education being the primary driver and the development of the physical infrastructure a very important element. In the short term, nevertheless, there are a number of important policy initiatives that can be fruitfully pursued to improve the environment for small business and entrepreneurial activities. A useful list of these is included in the SME issues paper issued by SMEDA. Others have also suggested various improvements from time to time.

We need to start by making the idea of business and wealth-creation a legitimate and desirable pursuit in our society. In general business activity has been viewed with suspicion and this view has arguably, been reinforced by the policies of nationalization, and the concentration of accountability measures almost exclusively on businessmen. Terms like Robber Baron, the twenty two families etc. have been used to generally denigrate businessmen. While no one would advocate the concentration of wealth in a few hands or be an apologist for unethical behavior, one cannot help feeling that somehow business has been singled out as the culprit for all ills.

We need to make a business career not only socially acceptable but desirable. How may national civil awards go to businessmen?

The broad areas of concern for us should be the following:

$\checkmark$ To attract the most innovative and resourceful individuals (also women) to start ventures.

$\checkmark$ To make it easy to start a business and to enter an industry.

$\checkmark$ To afford protection to physical and intellectual property rights.

$\checkmark$ To provide better education and training facilities for people in business or to prepare them for business.

$\checkmark$ To provide better access to new knowledge and research. The aim should be to improve productivity and product quality.

$\checkmark$ To make the availability of finance a reality for most enterprises. The venture capital industry has to be given a shot in arm. 
These are some of the major areas which can have an impact on entrepreneurial activity in Pakistan. The important part is to frame realistic policies and implement them effectively, especially making the provision of services accessible to those who can benefit from them.

Appendix

\section{Sector-Wise Break Up of Commercial Bank Loans}

\begin{tabular}{lrrrr}
\hline \multicolumn{1}{c}{ (Billion Rupees) } & June-04 & Sep-04 & \multicolumn{2}{c}{ Change during quarter } \\
\cline { 4 - 6 } & & & Amount & \% age \\
\hline Corporate Sector & $\mathbf{7 4 1 . 4}$ & $\mathbf{7 6 5 . 9}$ & $\mathbf{2 4 . 4}$ & 3.3 \\
Fixed Investments & 322.6 & 340.4 & 17.7 & 5.5 \\
Working Capital & 250.3 & 265.0 & 14.7 & 5.9 \\
Trade Finance & 168.5 & 160.5 & $(8.0)$ & $(4.7)$ \\
SMEs & $\mathbf{2 3 1 . 7}$ & $\mathbf{2 4 7 . 3}$ & $\mathbf{1 5 . 6}$ & $\mathbf{6 . 7}$ \\
Fixed Investments & 29.6 & 28.4 & $(1.2)$ & $(4.2)$ \\
Working Capital & 151.0 & 162.1 & 11.0 & 7.3 \\
Trade Finance & 51.1 & 56.8 & 5.8 & 11.3 \\
Agriculture Production & $\mathbf{1 0 8 . 7}$ & $\mathbf{1 1 7 . 8}$ & $\mathbf{9 . 1}$ & $\mathbf{8 . 3}$ \\
Consumer Finance & $\mathbf{1 0 3 . 2}$ & $\mathbf{1 2 5 . 8}$ & $\mathbf{2 2 . 6}$ & $\mathbf{2 1 . 9}$ \\
Credit Cards & 11.2 & 12.7 & 1.6 & 14.0 \\
Housing Loans & 8.2 & 12.4 & 4.1 & 49.3 \\
Auto Loans & 33.1 & 41.4 & 8.2 & 24.9 \\
Consumer Durables & 1.4 & 1.8 & 0.4 & 25.0 \\
Personal Loans & 49.2 & 57.5 & 8.3 & 16.8 \\
Commodity Operations & $\mathbf{9 0 . 0}$ & $\mathbf{8 5 . 0}$ & $\mathbf{( 5 . 0 )}$ & $\mathbf{( 5 . 6 )}$ \\
Staff Loans & $\mathbf{3 9 . 7}$ & $\mathbf{4 0 . 0}$ & $\mathbf{0 . 3}$ & $\mathbf{0 . 7}$ \\
Of which Housing Loans & 28.0 & 28.3 & 0.3 & 1.0 \\
Others & 36.1 & $\mathbf{2 9 . 7}$ & $\mathbf{( 6 . 4 )}$ & $\mathbf{( 1 7 . 8 )}$ \\
Total & $\mathbf{1 3 5 0 . 9}$ & $\mathbf{1 , 4 1 1 . 4}$ & $\mathbf{6 0 . 5}$ & $\mathbf{4 . 5}$ \\
\hline
\end{tabular}

Source: State Bank of Pakistan 


\section{References}

Altaf, Zafar 1988, Pakistan Entrepreneurs, Croom Helm.

Arif I. Rana. Jamshed H. Khan, Usman Asad and Sarfraz A. Mian: 2003, The SME PULSE: An exploratory study of the Performance of SMEs in Pakistan and the characterization of successful firms, Small and Medium Enterprise Center, LUMS.

Boettke, Peter J. \& Coyne, Christopher J., Entrepreneurship and Development: Cause or Consequence? JEL Classification: 0100 B53 M130.

Casson, Mark; 1982, The Entrepreneur - An Economic Theory Martin Robertson. Development of SME policy in Pakistan - SME Issues Paper SMEDA.

Drucker, P. 1985, Innovation and Entrepreneurship, William Heinemann.

GEM Project: Various reports www. gem consortium, org.

Kilby, Peter (Ed.). 1971, Entrepreneurship and Economic Development, The Free Press.

Lowrey, Y. The Entrepreneur and Entrepreneurship: A neoclassical approach, Presented Jan 2003 of ASSA Annual Meeting.

Nabi, Dr. I. et a1. 2005, Towards a Prosperous Pakistan - A strategy for rapid industrial growth. Ministry of Industries, Production and Special Initiatives, Govt. of Pakistan.

Nik Mohammad Affandi bin Nik Yusoff, 2002, Islam \& Business, Pelanduk Publications.

Papanek, G. 1967, Pakistan's Development Social Goals and Private Investment, Harvard University Press.

Weber, Max. 1958, The Protestant Ethic and the Spirit of Capitalism, Charles Scribner's Sons. 